\title{
PENGARUH INSENTIF DAN DISIPLIN KERJA DALAM MENINGKATKAN MOTIVASI KERJA PEGAWAI PADA KANTOR CAMAT KUALUH SELATAN KABUPATEN LABUHANBATU UTARA
}

\author{
Ade Irawan, Zulkarnain Nasution \\ Dosen Tetap Sekolah Tinggi Ilmu Ekonomi (STIE) Labuhanbatu
}

\begin{abstract}
ABSTRAK
Penelitian ini bertujuan untuk mengetahui pengaruh disiplin kerja terhadap kinerja pegawaipada Kantor Camat Kualuh Selatan Kabupaten Labuhanbatu Utara. Untuk mengetahuipengaruh pemberian intensif terhadap kinerja pegawai pada Kantor Camat Kualuh Selatan Kabupaten Labuhanbatu Utara. Untuk mengetahui pengaruh disiplin kerja dan pemberian intensif berpengaruh terhadap kinerja pegawai pada Kantor Camat Kualuh Selatan Kabupaten Labuhanbatu Utara. Jenis penelitian ini adalah penelitian asosiatif. Pengumpulan data dalam penelitian ini dilakukan melalui pendekatan survey dengan jenis penelitian deskriptif kuantitatif dengan menyebar kuesioner kepada 35 responden sedangkan populasi yang dijadikan dalam penelitian ini pegawai Kantor Camat Kualuh Selatan Kabupaten Labuhanbatu Utara. Teknik pengumpulan data dilakukan dengan wawancara, kuesioner dan studi dokumentasi. Teknik analisis data yang digunakan dalam penelitian ini adalah analisis deskriptif, analisis regresi linear berganda, pengujian hipotesis dengan menggunakan uji signifikan simultan (uji F), pengujian signifikan parsial (uji t), dan pengujian koefisien determinasi $\left(\mathrm{R}^{2}\right)$. Hasil penelitian ini menunjukkkan bahwa secara parsial bahwa variabel insentif tidak berpengaruh positif dan signifikan terhadap motivasi pegawai, secara parsial bahwa variabel disiplin kerja berpengaruh positif dan signifikan terhadap motivasi pegawai dan secara serempak bahwa variabel insentif dan disiplin kerja berpengaruh positif dan signifikan terhadap motivasi pegawai.
\end{abstract}

\section{Kata Kunci: Insentif, Disiplin Kerja, Motivasi Kerja.}

\section{PENDAHULUAN}

Secara umum tiap pimpinan instansi pemerintahan yang ada di Indonesia selalu berusaha memberikan semangat dan motivasi serta berbagai tunjangan kepada bawahanya agar memiliki kemampuan, kemauan, dan semangat tinggi untuk dapat menyelesaikan setiap tugas yang dibebankan kepadanya. Oleh karena itu, instansi pemerintahan terus berusaha, memberikan pandangan lebih banyak terhadap sumber daya manusia yang berada dalam ruang lingkup instansi pemerintahan tersebut.

Dalam memenuhi kebutuhan tersebut, instansi pemerintahan dapat menempuh dengan beberapa cara yang cukup efektif, yakni dengan cara yang meningkatkan sumber daya manusia berkualitas yang ada dalam instansi pemerintahan, mulai dari staf instansi pemerintahan sampai pegawai tetap. Sumber daya manusia menitikberatkan pada kenyataan bahwa manusia merupakan makhluk sosial yang saling berintraksi satu sama lain dalam pencapaian suatu tujuan.

Faktor sumber daya manusia sering kali menimbulkan masalah yang rumit dalam suatu instansi pemerintahan yang disebabkan karena adanya perbedaan-perbedaan seperti : tidak disiplinm, sifat keahlian, pengalaman, latar belakang dan reaksi yang ditimbulkan antar masing-masing pegawai, oleh karena itu pada dasarnya kelangsungan hidup instansi pemerintahan tergantung pada pegawai-pegawai yang berkerja dalam instansi pemerintahan tersebut. 
Cara instansi pemerintahan untuk memotivasi para pegawai yang memiliki kemampuan dan semangat kerja yang tinggi dalam meningkatkan pekerjaannya adalah dengan menegakkan disiplin kerja dan memberikan rangsangan secara fisik berupa insentif yang sesuai dengan prestasi kerja yang dihasilkan. Insentif yang umum terjadi umumnya berbentuk material, hal ini perlu diperhatikan dalam

pelaksananya karena insentif ini menyangkut aspek kehidupan para pegawai sebagai manusia.

Kantor Camat Kualuh Selatan Kabupaten Labuhanbatu Utara dalam meningkatkan motivasi kerja untuk menjadi lebih baik dari hari ke hari dalam bekerja tujuan lain untuk memotivasi pegawai sehingga diharapkan dapat meningkatkan kinerja pegawai. Adanya disiplin kerja dan pemberian insentif yang diberikan pemerintahaan Camat Kualuh Selatan Kabupaten Labuhanbatu Utara kepada pegawai dilakukan dengan cara bertahap namun sering juga mengalami perbedaan dan keterlambatan.

Permasalahan didalam meningkatkan motivasi pegawai Kantor Camat Kualuh Selatan Kabupaten Labuhanbatu Utara antara lain adanya membuat peraturan beserta sanksi tegas dan pemberian bonus yang tidak sesuai dan tidak tepat waktu, kompensasi tidak sesuai dengan standar yang ditetapkan, pemberian jaminan sosial yang belum efektif. Sehingga mengakibatkan pada penurunan motivasi kerja pegawai.

Berdasarkan uraian latar belakang tersebut penulis menganggap bahwa disiplin kerja dan pemberian insentif yang tepat merupakan hal yang perlu dilakukan untuk suatu instansi pemerintahan agar mendapat sumber daya manusia yang handal.

\section{Perumusan Masalah}

Adapun permasalahan dalam penelitian ini adalah :

1 Bagaimana disiplin kerja berpengaruh terhadap motivasi pegawai pada Kantor Camat Kualuh Selatan Kabupaten Labuhanbatu Utara?

2 Bagaimanapemberianintensif berpengaruh terhadap motivasi pegawai pada Kantor Camat Kualuh

Selatan Kabupaten Labuhanbatu Utara?

3 Bagaimanadisiplinkerjadan

pemberian intensif berpengaruh terhadap motivasi pegawai pada Kantor Camat Kualuh Selatan Kabupaten Labuhanbatu Utara?

\section{TINJAUAN PUSTAKA}

\section{Uraian Teoritis \\ Insentif}

Insentif sebagai sarana motivasi yang mendorong para pegawai untuk bekerja dengan kemampuan yang optimal, yang dimaksudkan sebagai pendapatan ekstra di luar gaji atau upah yang telah ditentukan. Pemberian insentif dimaksudkan agar dapat memenuhi kebutuhan para pegawai dan keluarga mereka. Istilah sistem insentif pada umumnya digunakan

untuk menggambarkan rencana-rencana pembayaran upah yang dikaitkan secara langsung atau tidak langsung denganberbagai standar kinerja pegawai atau profitabilitas organisasi.

Kompensasi dan insentif mempunyai hubungan yang sangat erat, di mana insentif merupakan komponen dari kompensasi dan keduanya sangat menentukan dalam pencapaian tujuan dan sasaran organisasi secara keseluruhan. Insentif dapat dirumuskan sebagai balas jasa yang memadai kepada pegawai yang prestasinya melebihi standar yang telah ditetapkan. Insentif merupakan suatu faktor pendorong bagi pegawai untuk bekerja lebih baik agar kinerja pegawai dapat meningkat.

Untuk memperoleh pengertian yang lebih jelas tentang insentif, di bawah ini ada beberapa ahli manajemen mengemukakan pengertian mengenai insentif. Menurut Hasibuan (2001:117), 
mengemukakan bahwa :"Insentif adalah tambahan balas jasa yang diberikan kepada karyawan tertentu yang prestasinya di atas prestasi standar. Insentif ini merupakan alat yang dipergunakan pendukung prinsip adil dalam pemberian kompensasi”.

Menurut Mangkunegara (2002: 89), mengemukakan bahwa : "Insentif adalah suatu bentuk motivasi yang dinyatakan dalam bentuk uang atas dasar kinerja yang tinggi dan juga merupakan rasa pengakuan dari pihak organisasi terhadap kinerja karyawan dan kontribusi terhadap organisasi (perusahaan)".

Menurut Pangabean (2002:77), mengemukakan bahwa : "Insentif merupakan imbalan langsung yang dibayarkan kepada karyawan karena prestasi melebihi standar yang ditentukan. Dengan

mengasumsikan bahwa uang dapat mendorong karyawan bekerja lebih giat lagi, maka mereka yang produktif lebih menyukai gajinya dibayarkan berdasarkan hasil kerja". Menurut Handoko (2002:176), mengemukakan bahwa :"Insentif adalah perangsang yang ditawarkan kepada para karyawan untuk melaksanakan kerja sesuai atau lebih tinggi dari standar-standar yang telah ditetapkan".

Jadi menurut pendapat-pendapat para ahli di atas dapat penulis simpulkan, bahwa insentif adalah dorongan pada seseorang agar mau bekerja dengan baik dan agar lebih dapat mencapai tingkat kinerja yang lebih tinggi sehingga dapat membangkitkan gairah kerja dan motivasi seorang pegawai, jadi seseorang mau bekerja dengan baik apabila dalam dirinya terdapat motivasi, yang menjadi masalah adalah bagaimana pula. Pada prinsipnya pemberian insentif menguntungkan kedua belah pihak.

Perusahaan mengharapkan adanya kekuatan atau semangat yang timbul dalam diri penerima insentif yang mendorong mereka untuk bekerja dengan lebih baik dalam arti lebih produktif agar tujuan yang ingin dicapai oleh perusahaan/instansi dapat terpenuhi sedangkan bagi pegawai sebagai salah satu alat pemuas kebutuhannya.

\section{Disiplin Kerja}

Menurut Satrohadiwiryo (2002:291) menjelaskan arti Disiplin sebagai berikut : "Suatu sikap menghormati, menghargai patuh dan taat terhadap peraturan-peraturan yang berlaku, baik yang tertulis maupun tidak, serta sanggup menjalankannya, serta tidak mengelak untuk menerima sanksi-sanksi apabila ia melanggar tugas dan wewenag yang diberikan kepadanya.

Disiplin kerja menurut Rivai (2005:444) adalah : "Suatu alat yang digunakan para manajer untuk berkomunikasi dengan karyawan agar mereka bersedia mengubah suatu perilaku serta sebagai suatu upaya untuk meningkatkan kesadaran dan kesediaan seseorang mentaati semua peraturan perusahaan dan norma-norma sosial yang berlaku.

Menurut Sinungan (2000:146) menjelaskan bahwa disiplin kerja itu " Sikap mental yang tercermin dalam perbuatan atau tingkah laku perorangan, kelompok atau masyarakat berupa kepatuhan atau ketaatan terhadap peraturan-peraturan yang di tetapkan baik oleh pemerintah etik, norma, dan kaidah yang berlaku dalam masyarakat untuk tujuan tertentu". Selanjutnya Keith Davis (1985:366) yang di kutip oleh Anwar

Prabu Mangkunegara (2001:129) "Dicipline is management action to enforce organization standar" ( Disiplinkerja diartikan sebagai pelaksanaan manajemen untuk memperteguh pedoman-pedoman organisasi.

Berdasarkan pengertian-pengertian diatas dapat disimpulkan bahwa yang dimaksud dengan disiplin kerja adalah sikap mental yang tercermin dalam perbuatan perorangan maupun kelompok berupa kepatuhan atau ketaatan terhadap peraturan-peraturan yang di tetapkan untuk memperteguh pedoman-pedoman organisasi.

\section{Motivasi}


Pengertian Motivasi adalah serangkaian sikap dan nilai-nilai yang mempengaruhi individu untuk mencapai hal yang spesifik sesuai dengan tujuan individu. Sikap dan nilai tersebut merupakan suatu yang invisible yang memberikan kekuatan untuk mendorong individu bertingkah laku dalam mencapai tujuan (Rivai : 2005: hal. 455). Dorongan tersebut terdiri dan 2 (dua) komponen, yaitu: arah perilaku (kerja untuk mencapai tujuan), dan kekuatan perilaku (seberapa kuat usaha individu dalam bekerja). Motivasi meliputi perasaan unik, pemikiranan dan pengalaman masa lalu yang merupakan bagian dari

hubungan internal dan eksternal lembaga. Selain itu motivasi dapat pula diartikan sebagai dorongan individu untuk melakukan tindakan karena mereka ingin melakukannya. Apabila individu termotivasi, mereka akan membuat pilihan yang positif untuk melakukan sesuatu, karena dapat memuaskan keinginan mereka. (Rivai : 2005: hal. 456).

Pada dasarnya motivasi dapat memacu staf untuk bekerja keras sehingga dapat mencapai tujuan mereka. Hal ini akan meningkatkan produktivitas kerja staf sehingga berpengaruh pada pencapaian tujuan lembaga. Sumber motivasi ada tiga faktor, yakni (1) kemungkinan untuk

berkembang, (2) jenis pekerjaan dan (3) apakah mereka dapat merasa bangga menjadi bagian dari lembaga tempat mereka bekerja. Di samping itu terdapat beberapa aspek yang berpengaruh terhadap motivasi kerja staf, yakni: rasa aman dalam bekerja, mendapatkan gaji yang adil dan kompetitif, lingkungan kerja yang menyenangkan, penghargaan atas prestasi kerja dan yang menjelaskan tentang "apa" dari motivasi.

Pengertian dari motivasi yang diungkapkan oleh beberapa para ahli diantaranya sebagai berikut:

Menurut Mathis danJackson (2001:89) mengemukakan motivasi adalah merupakan hasrat didalam seseorang yang menyebabkan orang tersebut melakukan tindakan. Rivai (2004-455) Motivasi adalah serangkaian sikap dan nilai-nilai yang mempengaruhi individu untuk mencapai hal yang sepesifik sesuai dengan tujuan individu.

Motivasi adalah faktor-faktor yang mengarahkan dan mendorong prilaku atau keinginan seseorang untuk melakukansuatu kegiatan yang dinyatakan dalam bentuk usaha yang keras dan lemah. Marihot Tua Efendi (2002:321). Beberapa pendapat di atas dapat disimpulkan bahwa Motivasi adalah dorongan dalam mengarahkan individu yang merangsang tingkah laku individu serta organisasi untuk melakukan tindakan (kegiatan) dalam mencapai tujuan yang diharapkan.

\section{Hipotesis Penelitian}

Hipotesis adalah suatu perumusan sementara mengenai suatu hal yang dibuat untuk menjelaskan hal itu dan juga

dapat menuntun/mengarahkan penyelidikan selanjutnya. Hipotesis yang penulis kemukakan dalan penelitian ini, diduga bahwa:

c. Pemberian insentif kerja berpengaruh terhadap motivasi pegawai pada Kantor Camat Kualuh Selatan Kabupaten Labuhanbatu Utara.

d. Disiplin kerja berpengaruh terhadap motivasi pegawai pada Kantor Camat KualuhSelatanKabupaten

Labuhanbatu Utara..

g. pemberian intensif dan Disiplin kerja berpengaruh terhadap motivasi pegawai pada Kantor Camat Kualuh Selatan Kabupaten Labuhanbatu Utara.

\section{METODE PENELITIAN}




\section{Populasi}

Populasi adalah keseluruhan dari sekumpulan elemen atau objek dan subjek yang memiliki sejumlah karakteristik umum yang diminati oleh peneliti untuk dipelajari, diteliti dan kemudian ditarik kesimpulan (Sugiyono, 2006). Dalam penelitian ini yang menjadi populasi adalah seluruh pegawai Kantor Camat Kualuh Selatan Kabupaten Labuhanbatu Utara sebanyak 35 orang. Oleh karena itu sampel dalam penelitian ini adalah keseluruhan pegawai Kantor Camat Kualuh Selatan Kabupaten Labuhanbatu Utara berjumlah 35 orang. Adapun metode sampling jenuh,yaitu teknikpenentuan sampel apabila semua populasi digunakan sebagai sampel.

\section{Metode Analisis Data Analisis Statistik Deskriptif}

Merupakan cara merumuskan dan menafsirkan data yang ada sehingga memberikan gambaran yang jelas tentang data yang diteliti.

\section{Analisis Regresi Linier Berganda}

Metode regresi linear berganda dengan alasan variabel bebas terdiri dari beberapa variabel. Berdasarkan hubungan dua variabel yang dinyatakan dengan persamaan linear dapat digunakan untuk membuat prediksi (ramalan) tentang besarnya nilai Y (variabel dependen) berdasarkan nilai $\mathrm{X}$ tertentu (variabel independen). Ramalan (prediksi) tersebut akan menjadi lebih baik bila kita tidak hanya memperhatikan satu variabel yang mempengaruhi (variabel independen) sehingga menggunakan analisis regresi linear berganda.

\section{HASIL DAN PEMBAHASAN}

\section{Hasil Persamaan Regresi Linier Berganda}

Analisis regresi linear berganda bertujuan untuk mengetahui pengaruh dari variabel-variabel independen terhadap variabel dependen, dapat dilihat pada Tabel 1 berikut ini :

\section{Tabel 1}

\section{Hasil Analisis Regresi Linier Berganda}

\begin{tabular}{|l|c|c|c|c|l|}
\hline Model & $\begin{array}{c}\text { Unstandardi } \\
\text { zed }\end{array}$ & $\begin{array}{c}\text { Standardi } \\
\text { zed } \\
\text { Coefficie } \\
\text { nts }\end{array}$ & & \\
& Coefficients & & \\
\cline { 2 - 4 } & $\mathrm{B}$ & $\begin{array}{c}\text { Std. } \\
\text { Error }\end{array}$ & Beta & $\mathrm{t}$ & Sig. \\
\hline (Constant) & 1.517 & 1.312 & & 1.157 & $\begin{array}{l}.25 \\
6 \\
\text { X1 }\end{array}$ \\
X2 & .272 & .170 & .290 & 1.597 & 0 \\
.512 & .146 & .639 & 3.519 & .00 \\
\hline
\end{tabular}

a. Dependent Variable: Y

Sumber : Data Diolah (2014) 
Tabel 1 menunjukan bahwa model yang digunakan untuk menduga pengaruh tersebut adalah :

$$
Y=1,517+0,272 X 1+0,512 X 2+e
$$

\section{Keterangan :}

3. Koefisien regresi konstanta sebesar 1,517 mempunyai arti jika ada atau variabel insentif dan disiplin kerja, maka motivasi kerja akan sebesar - 1,517.

4. Koefisien regresi insentif sebesar 0,272 mempunyai arti bahwa setiap terjadi penambahan insentif sebesar 0,272 maka motivasi kerja sebesar 1 kali.

5. Koefisien regresi disiplin kerja sebesar 0,512 mempunyai arti bahwa setiap terjadi penambahan disiplin kerja sebesar 0,512 maka motivasi kerja sebesar 1 kali.

\section{Analisis Koefisien Determinasi $\left(\mathbf{R}^{\mathbf{2}}\right)$}

Analisis koefisien determinan digunakan untuk melihat seberapa besar pengaruh variabel bebas terhadap variabel terikat. Hasil pengujian koefisien determinasi dapat dilihat dari Tabel 2 sebagai berikut :

\section{Tabel 2}

\section{Hasil Koefisien Determinasi $\left(\mathbf{R}^{2}\right)$}

Model Summary ${ }^{\mathrm{b}}$

\begin{tabular}{|c|c|c|c|c|}
\hline Model & $\mathbf{R}$ & $\begin{array}{c}\text { R } \\
\text { Squar } \\
\text { e }\end{array}$ & $\mid \begin{array}{c}\text { Adjuste } \\
\mathbf{d} \\
\text { R } \\
\text { Square }\end{array}$ & \begin{tabular}{|c} 
Std. \\
Error \\
of \\
the \\
Estima \\
te
\end{tabular} \\
\hline $\begin{array}{c}\text { dimension } \\
0\end{array}$ & $.912^{\mathrm{a}}$ & .832 & .822 & $\begin{array}{c}1.0127 \\
7\end{array}$ \\
\hline
\end{tabular}

a. Predictors:

(Constant), X2, X1

b. Dependent Variable: Y

\section{Sumber : Data Diolah (2014)}

Pada bagian ini ditampilkan nilai $\mathrm{R}, \mathrm{R}^{2}$, adjusted $R^{2}$, dan standard error.

2. Nilai R sebesar 0,912 sama dengan $91,2 \%$ yang menunjukan bahwa hubungan antara variabel insentif dan disiplin kerja terhadap motivasi kerja cukup erat.

3. Besarnya nilai koefisien determinasi 0,832 atau sama dengan $83,2 \%$. Nilai tersebut berarti bahwa sebesar $83,2 \%$ menegaskan bahwa motivasi kerja dapat dijelaskan melalui variabel insentif dan disiplin kerja.

\section{Pengujian Hipotesis}

\section{Hasil Uji Serempak (Uji F)}

Uji F ini dilakukan untuk menguji secara serempak apakah disiplin kerja dan sanksi berpengaruh terhadap motivasikerja, dapat dilihat pada Tabel 3 berikut : 
Tabel 3

Hasil Uji Serempak (Uji F)

\begin{tabular}{|l|c|c|c|c|c|}
\hline Model & $\begin{array}{c}\text { Sum of } \\
\text { Squar } \\
\text { es }\end{array}$ & df & Square & F & Sig. \\
\hline 1 & & & & & \\
Regressio & 162.77 & & & 79.34 & \\
$\mathrm{n}$ & 7 & 2 & 81.389 & 9 & $.000^{\mathrm{a}}$ \\
Residual & 32.823 & 32 & 1.026 & & \\
& 195.60 & & & & \\
Total & 0 & 34 & & & \\
\hline
\end{tabular}

a. Predictors: (Constant), X2, X1

b. Dependent Variable: Y

\section{Sumber : Data Diolah (2014)}

Berdasarkan Tabel 3 menunjukkan bahwa hasil uji $\mathrm{F}$ sebesar79,349 dengan tingkat signifikan sebesar 0.000 sedangkan nilai $\mathrm{F}$ tabel sebesar 3,276. Jika dibandingkan nilai Fhitung $(79,349)>$ Ftabel $(3,276)$ pada alpha $5 \%$ maka disimpulkan bahwa secara serempak variabel insentif dan disiplin kerja berpengaruh positif dan signifikan terhadap motivasi kerja.

\section{Hasil Uji Parsial (Uji t)}

Uji parsial (uji t) dilakukan untuk menguji secara parsial (individu) apakah insentif dan disiplin kerja berpengaruhterhadap motivasi kerja, dapat dilihat pada Tabel 4 berikut :

Tabel 4

Hasil Uji Parsial (Uji t)

\begin{tabular}{|c|c|c|c|c|c|}
\hline \multirow[t]{2}{*}{ Model } & $\begin{array}{r}\text { Unst } \\
\text { d } \\
\text { Coeff } \\
\end{array}$ & $\begin{array}{l}\text { andar } \\
\text { ize } \\
\text { d } \\
\text { icients }\end{array}$ & $\begin{array}{c}\text { Standard } \\
\text { ize } \\
\\
\text { d } \\
\text { Coefificie } \\
\text { nts }\end{array}$ & & \\
\hline & B & \begin{tabular}{|l|} 
Std. \\
Error
\end{tabular} & Beta & $\mathrm{t}$ & Sig \\
\hline 1 & & & & & \\
\hline $\begin{array}{l}\text { (Consta } \\
\mathrm{nt}\end{array}$ & 1.517 & 1.312 & & 1.157 & $\begin{array}{l}.25 \\
6\end{array}$ \\
\hline ) & & & & & 12 \\
\hline $\mathrm{X} 1$ & .272 & .170 & .290 & 1.597 & 0 \\
\hline $\mathrm{X} 2$ & .512 & .146 & .639 & 3.519 & 1 \\
\hline
\end{tabular}




\section{a a. Dependent Variable: Y}

\section{Sumber : Data Diolah (2014)}

Berdasarkan Tabel 4 terlihat bahwa nilai thitunguntuk variabel insentifsebesar 1,597 dan disiplin kerja sebesar 3,519 dengan nilai signifikan untuk masing-masing variabel independen $(0,120)$; $(0,001)$. Sedangkan untuk nilai ttabelpada tabel statistik distribusi t denganlevel of test $\alpha=5 \%$ dan $\mathrm{df} 1=35$ sebesar1,681. Berdasarkan kriteria bahwa jika nilai thitung > ttabel yakni $(1,597<1,689)$; $(3,519>1,689)$ sehingga dapat disimpulkan bahwa variabel insentif dan disiplin kerja berpengaruh positif dan signifikan terhadap motivasi kerja.

\section{Pembahasan}

Dari hasil pengujian secara serempak (uji F) bahwa nilai Fhitung $(79,349)>$ Ftabel $(3,276)$ pada alpha 5\% maka disimpulkan bahwa secara serempak variabel insentif dan disiplin kerja berpangaruh positif dan signifikan terhadap motivasi kerja. Berpengaruh positif dan signifikannya seluruh variabel independen terhadap variabel dependen memberikan makna bahwa seluruh variabel independen dan dependen memiliki keterkaitan yang erat.

Sedangkan variabel independen yaitu disiplin kerja memiliki nilai thitung $>$ ttabel atau 3,519>1,689 dengan nilaiprobabilitas sebesar 0,000 < 0,05, maka Ha ditolak dan merupakan variabel independen disiplin kerja memiliki pengaruh paling dominan terhadap variabel motivasi kerja.

Dari hasil penelitian dilihat bahwa variabel independen yaitu insentif memiliki nilai thitung $>$ ttabel atau 1,597 < 1,689 dengan nilai probabilitas sebesar $0,120>0,05$, maka hipotesis

Ha diterima yang berarti insentif tidak berpengaruh positif dan signifikan terhadap motivasi kerja. Hal ini dapat dijelaskan insentif

sebagai sarana motivasi yang mendorong para pegawai untuk bekerja dengan kemampuan yang optimal, yang dimaksudkan sebagai pendapatan ekstra di luar gaji atau upah yang telah ditentukan.

\section{KESIMPULAN DAN SARAN}

\section{Kesimpulan} berikut :

Berdasarkan uraian hasil penelitian dan pembahasan, dapat disimpulkan sebagai

2. Secara parsial bahwa variabel insentif tidak berpengaruh positif dan signifikan terhadap motivasi pegawai.

1 Secara parsial bahwa variabel disiplin kerja berpengaruh positif dan signifikan terhadap motivasi pegawai.

2 Secara serempak bahwa variabel insentif dan disiplin kerja berpengaruh positif dan signifikan terhadap motivasi pegawai.

\section{Saran}

Berdasarkan hasil analisis dan kesimpulan penelitian, maka diajukan beberapa saran sebagai berikut : 
1. Kantor Camat Kualuh Selatan Kabupaten Labuhanbatu Utara, sebaiknya memperhatikan insentif yang sesuai dengan ketetapan dan memberikannya pada pegawai yang memiliki motivasi baik dalam bekerja.

2. Kantor Camat Kualuh Selatan Kabupaten Labuhanbatu Utara, sebaiknya meningkatkan insentif dan disiplin kerja melalui kebijakan-kebijakan yang telah ditetapkan agar seluruh pegawai memiliki sikap yang sopan dan santun dalam bekerja.

3. Kantor Camat Kualuh Selatan Kabupaten Labuhanbatu Utara meningkatkan disiplin kerja secara tegas kepada pegawai yang disiplin agar mempengaruhi motivasi pegawai.

\section{DAFTAR PUSTAKA}

Arikunto, Suharsimi, 2000. Manajemen Penelitian. Penerbit PT. Rineka Cipta, Jakarta.

Damayanti. 2009. Motivasi KerjaKaryawan Terhadap Produktivitas Kerja karyawan CV. Bening Natural Furniture Di Semarang. Jurnal Manajemen

Danim,Sudarman.2004.Motivasi, Kepemimpinan dan Efektivitas Kelompok. Penerbit Rineka Cipta, Jakarta.

Dessler, Gary,2004. Manajemen Sumber Daya Manusia.Edisi 9. Jilid 1. Kelompok Gramedia, Jakarta.

Ginting, Paham dan Helmi, 2008. Filsafat Ilmu dan Metode Penelitian. Penerbit USU Press. Pratama. 2009. Pengaruh Kepemimpinan dan Lingkungan Kerja Terhadap Semangat Kerja Karyawan Bagian Produksi PT. Nyonya Meneer Semarang. Jurnal Manajemen.

Rivai,Veithzal, 2004, Manajemen Sumber Daya Manusia untuk Perusahaan. PT. Raja Grafindo Persada, Jakarta.

Sedarmayanti,2001, Sumber Daya Manusia dan Produktivitas Kerja. Mandar Maju, Bandung.

Siagian, Sondang P, 2002.Manajemen Sumber Daya Manusia. Bumi ksara, Jakarta.

Situmorang,Syafrizal Helmi.2009. Analisis Data Penelitian. Cetakan Kedua USU Press, Medan

Sugiyono,2008. Metode Penelitian Bisnis. Alfabeta, Bandung.

Zainun. 2000. Manajemen Sumber Daya Manusia. PT. Ghalia Indonesia, Jakarta 